\title{
Promoting sustainable tourism in the Pacific Forum Island countries
}

\author{
V. Saverimuttu ${ }^{1,2}$ \& M. E. Varua ${ }^{2}$ \\ ${ }^{1}$ Australian Institute of Higher Education, Australia \\ ${ }^{2}$ School of Business, University of Western Sydney, Australia
}

\begin{abstract}
Tourism is vital to the sustainability and development of the Pacific Forum Island economies. Australia and New Zealand are major markets for these island nations followed by the US and Japan. The region is prone to tropical cyclones, in most years, typically occurring during the months of November to April. This paper investigates the impact of tourism on economic growth and its contribution to employment in Fiji, Samoa, Tonga and Vanuatu. The paper also examines the impact of income (GDP) growth in visitor origin countries (Australia, New Zealand and the US), the inertial effect on travel destination choice, investment in travel and tourism and extreme weather conditions on tourism receipts in these countries using panel data analysis. In 2012, tourism's contribution to GDP ranged between an estimated $14.2 \%$ of GDP (Tonga) and 50.7\% (Vanuatu). The contribution to employment ranged between $13.8 \%$ (Tonga) and $44.9 \%$ (Vanuatu) of total employment. Travel and Tourism investment ranged between $11.1 \%$ (Tonga) of total investment and $28.1 \%$ (Fiji). The variable for investment in travel and tourism was not significant which was not surprising. The variable for extreme weather was also not significant, suggesting that other factors mitigate the impact of the seasonal cyclones on tourist arrivals. The impact of Australian GDP was significant but negative, implying that Australian tourists preferred to travel elsewhere rather than to Pacific Island destinations when their income increased. The impact of all other variables tested on tourism receipts was significant and positive. The paper concludes with recommendations to improve the long term sustainability of tourism in this region.
\end{abstract}

Keywords: tourism and economic growth, Pacific Islands, sustainable tourism, extreme weather patterns, tourism strategies. 


\section{Introduction}

Tourism is of vital importance to island economies, especially for those in the Pacific that lack industry and are dependent on this sector as a source of revenue, foreign currency and employment [1]. The islands in the Pacific are naturally attractive tourist destinations with their 'sun and sand' image and exotic ambience and in recent years travel and tourism forecasts for this region have been extremely favourable. In the Oceania region travel and tourism contributed $10.8 \%$ of GDP (total contribution) in 2013 and is expected to rise by $2.9 \%$ in 2014 and by $3.2 \%$ pa to US $\$ 264.8$ billion in 2024 [2]. At the same time limited resources, lack of infrastructure and other development constraints, environmental vulnerabilities and the lack of proper plans and procedures hinder the sustainable development of tourism in these economies. Recognising this, the Waiheke Declaration on Sustainable Economic Development, signed in 2011 by the leaders of the Pacific Forum Island countries (FICs), includes a commitment to support growth in the tourism sector [3].

The FIC group consists of 16 self-governing independent states including Australia and New Zealand, the rest being Polynesian and Melanesian island nations in the region of Oceania. New Caledonia and French Polynesia are associate members while Tokelau, Wallis and Futuna, American Samoa, Guam and the Commonwealth of the Northern Marianas along with some international organisations such as the United Nations are Forum observers. The Forum was founded in 1971 with Australia, Cook Islands, Fiji, Nauru, New Zealand, Tonga and Samoa being the founding members. In 1996, the FIC leaders decided that annual meetings of the Forum Economic Ministers would improve regional and subregional co-operation in dealing with issues such as good governance, economic management and the ongoing sharing of experiences in economic reform. In addition this collaboration includes a stocktake and feedback mechanism which allows for the identification of areas where a greater concentration of effort and resources are required [4].

Australia and New Zealand are the major markets for the other FICs in the Oceania region followed by the US and Japan. Thus excluding Australia and New Zealand, the tourism sector contributed approximately 400,000 jobs directly and indirectly in 2012 in the remaining FICs [5]. These FICs rely on Australia and New Zealand for assistance with their development programmes. Among these countries Fiji (US\$ 3,908 million in 2012) and Papua New Guinea (US\$15,654 million in 2012) are the largest FICs in terms of GDP. In the rest GDP is less than US\$1000 million [6]. Tourism is the key sector for income generation and socio-economic development in a number of these FICs and the vulnerability of this sector is worsened by the lack of adequate resources to fund infrastructure development as well as to prepare for the impact of climate change on the sector. The region is also prone to tropical cyclones, in most years, which typically occur during the months of November to April. Thus, these FICs require both strategic and tactical financial and non-financial assistance to ensure the long term viability of their tourism sectors. The South Pacific Tourism Organisation (SPTO) has recently commenced a capacity building programme 
funded by the European Development Fund (EDF) to sustainably develop the region's tourism sector [3].

This paper investigates the impact of tourism on economic growth and its contribution to employment in Fiji, Samoa, Tonga and Vanuatu. The paper also examines the impact of income (GDP) growth in visitor origin countries (Australia, New Zealand and the US), the inertial effect on travel destination choice, investment in travel and tourism and extreme weather conditions on tourism receipts in these countries using panel data analysis. The paper concludes with recommendations to improve the long term sustainability of tourism in this region.

\section{Overview of selected FICs}

Fiji and Vanuatu are a part of the Melanesian region while Samoa and Tonga are located in the Polynesian region. These four FICs are selected as a focus of this study partly to represent both regions of the Pacific and partly due to the great disparity in the number of tourists visiting the countries in each region. Comparative data on selected economic and tourism related indicators are reported in the Table 1 below [6-10].

Table 1: Comparative data on selected economic and tourism related indicators.

\begin{tabular}{|c|c|c|c|c|}
\hline Countries & Fiji & Samoa & Tonga & Vanuatu \\
\hline GDP US \$ millions -2012 & 3908 & 684 & 472 & 787 \\
\hline World ranking & 155 & 181 & 184 & 177 \\
\hline Tourist arrivals '000s -2011 & 675 & 121 & 46 & 94 \\
\hline $\begin{array}{r}\text { Tourism receipts US \$ millions - } 2011 \\
\text { US \$ millions - 2009 }\end{array}$ & $\begin{array}{l}599.0 \\
\text { n.a }\end{array}$ & $\begin{array}{l}134.9 \\
\text { n.a }\end{array}$ & $\begin{array}{l}\text { n.a } \\
16.8\end{array}$ & $\begin{array}{l}252.0 \\
\text { n.a }\end{array}$ \\
\hline Rural population '000s & 414.8 & 150.1 & 79.99 & 184.4 \\
\hline Urban population '000s & 453.6 & 37.3 & 24.52 & 61.2 \\
\hline Total population ' $000 \mathrm{~s}-2011$ & 868.4 & 187.4 & 104.51 & 245.6 \\
\hline FDI US\$ million & 204.3 & 14.8 & 10.4 & 58.1 \\
\hline GDP per capita US \$ 2011 & $\$ 4,325$ & $\$ 3,361$ & $\$ 4,046$ & $\$ 3,252$ \\
\hline $\begin{array}{lr}\text { Tourism sector contribution to GDP } \\
\text { - direct plus indirect contribution in } 2012 \\
\text { - direct contribution } & 2010 \\
\end{array}$ & $35.8 \%$ & $\begin{array}{l}\text { n.a } \\
30 \%\end{array}$ & $14.2 \%$ & $50.7 \%$ \\
\hline $\begin{array}{l}\text { Tourism sector contribution to employment } \\
\text { - direct plus indirect contribution in } 2012 \\
\text { - jobs } \\
\text { - direct contribution } \\
\text { - jobs }\end{array}$ & $\begin{array}{l}32.3 \% \\
108,500\end{array}$ & $\begin{array}{l}\text { n.a } \\
\text { n.a } \\
10 \% \\
5400\end{array}$ & $\begin{array}{l}13.8 \% \\
4,500\end{array}$ & $\begin{array}{l}44.9 \% \\
30,500\end{array}$ \\
\hline
\end{tabular}

\subsection{Fiji}

Among the 16 FICs excluding Australia and New Zealand, Fiji is the most developed economy even though it has a large subsistence sector. The island is richly endowed with forest, mineral and fish resources. The country's industrial activity is based on an inefficient sugar processing industry, construction, a declining garment industry and tourism. Major foreign currency earners are sugar exports, remittances and the tourism sector even though the coup in 2006 
saw a decline in tourist arrivals in 2007. With an uncertain future facing the sugar and garment industries and declining remittances from abroad after the coup, tourism is expected to play a major role in the Fijian economy. Tourists generally travel to Fiji for holiday purposes and in 2012, approximately 51\% originated from Australia followed by $16 \%$ from New Zealand and $9 \%$ from the United States [11-13].

\subsection{Samoa}

Traditionally the Samoan economy was based on agriculture, limited forestry and overseas remittances. Semi-subsistence agriculture and plantations employ the majority of the labour force and are the source of products processed by the manufacturing sector. After two devastating cyclones in 1990 and 1991 and taro leaf blight in 1995, commercial fishing, small scale manufacturing and tourism were recognised as possible engines of future growth [14-15]. However, tourism has since become especially important for growth, foreign currency and employment following the more recent declines in the fisheries and agriculture industries [8]. The majority of visitors to Samoa originate from the Oceania region with nearly $44 \%$ from New Zealand, followed by approximately $24 \%$ from Australia and 15\% from neighbouring American Samoa. Approximately $6 \%$ of the tourists originate from the United States. The majority of the visitors are Samoans now resident abroad mostly in New Zealand visiting relatives [16].

\subsection{Tonga}

A very narrow agricultural export base and fish account for nearly two thirds of Tonga's exports with a high proportion of food being imported from New Zealand. Foreign currency earners are mainly remittances from Tongans living abroad followed by tourism receipts $[9,12]$. In Tonga, Tourisms main attraction is its whale watching industry, an important industry in the Oceania region, and the opportunity to swim with humpback whales. This industry became possible due to a Royal decree which banned the harvesting of whales and has grown to about 19 operators, 9 of which are fully owned by Tongans. The industry has also developed strict guidelines to protect the whales due to concerns about the welfare of the whales [17]. 48\% of visitors to Tonga are from New Zealand, followed by $22 \%$ from Australia and 13\% from the United States [18].

\subsection{Vanuatu}

With a relatively high dependence on subsistence agriculture, Vanuatu is classified as a least developed country. With negligible mineral deposits, fishing, offshore financial services and tourism are the other industries supporting the economy. Although dependence on tourism is high, development of the sector to a large extent has occurred on Efate, the main island, with outer islands being 
neglected. Apart from tourism receipts, remittance flows, following the introduction of the Recognized Seasonal Employer Scheme by New Zealand and later the Seasonal Pilot Worker Scheme by Australia, are another important source of foreign currency [19-20]. Nearly $62 \%$ of visitors to Vanuatu originate from Australia, followed by $12 \%$ from New Zealand and 12\% from New Caledonia, mainly Melanesians of Vanuatu origin visiting relatives especially during the months of December and January. Approximately $6 \%$ of visitors originate from North America mainly the United States [21].

\section{Methodology and analysis of results}

Two models are specified for this study. Model 1 estimates the impact of the inertial effect on travel destination choice and income growth in Australia, New Zealand and the United States on tourism receipts in the FICs. The impact of capital expenditure on the tourism sector and extreme weather were initially included but proved to have an insignificant impact and are therefore excluded from Model 1. Model 2 tests the impact of tourism, foreign direct investment (FDI), population and extreme weather on the GDP of the FICs.

The proxy for tourism in Model 2 is derived using the redefined Model 1. All other data are from secondary sources based on government statistics. The period of analysis is from 1996 to 2011. Panel data analysis using STATA is applied to estimate both models. To control for omitted variables that differ between the countries but are constant over time fixed effects regression is used in the analysis. The Im-Pesaran-Shin unit root test, the Breusch-Pagan LM test for contemporaneous correlation and a modified Wald test for group wise heteroskedasticity were conducted to verify the robustness of the models.

\subsection{The models}

The equations representing the two models are given below and a definition of the variables and the results of the analysis with coefficients, $p$ values, and significance levels at $1 \%, 5 \%$ and $10 \%$ are displayed in Tables 2 and 3 following equations (1) and (2).

$$
\begin{aligned}
& \operatorname{lnRect}_{i, t}=\beta_{i}+\beta_{2} \operatorname{lnRect}_{i, t-1}+\beta_{3} \operatorname{lnGDPOz_{i,t-1}} \\
& +\beta_{4} \ln G D P N Z_{i, t-1}+\beta_{5} \ln G D P U S_{i, t-1}+\varepsilon_{i, t} \\
& \text { OwnGDP } P_{i, t}=\alpha_{i}+\alpha_{2} \operatorname{lnRec}_{i, t}+\alpha_{3} F D I_{i, t-1}+\alpha_{4} P_{o p} p_{i, t} \\
& +\alpha_{5} \mathrm{CyclOz}_{i, t}+\varepsilon_{i, t}
\end{aligned}
$$


Table 2: Results for Equation (1).

\begin{tabular}{|c|c|c|}
\hline $\begin{array}{c}\text { Variable } \\
\text { Name }\end{array}$ & Definition & $\begin{array}{c}\text { Model } 1 \\
\text { lnRect }_{\mathrm{t}}\end{array}$ \\
\hline $\operatorname{lnRect}_{t-1}$ & Log of tourism receipts of country $i$ in period $t-1$ & $\begin{array}{c}0.6458 \\
(0.0000)^{* * *}\end{array}$ \\
\hline $\ln G D P O z_{t-1}$ & Log of Australian GDP in period $t-1$ & $\begin{array}{c}-0.5107 \\
(0.0200)^{* *}\end{array}$ \\
\hline $\ln G D P N Z_{t-1}$ & Log of New Zealand GDP in period $t-1$ & $\begin{array}{c}0.7013 \\
(0.0000)^{* * *}\end{array}$ \\
\hline $\ln G D P U s_{t-1}$ & Log of United States GDP in period $t-1$ & $\begin{array}{c}0.4807 \\
(0.0230)^{* *}\end{array}$ \\
\hline cons & Constant & $\begin{array}{c}-11.7685 \\
(0.0030)^{* * *}\end{array}$ \\
\hline
\end{tabular}

$* * *, * *, *$ significant at $1 \%, 5 \%$ and $10 \%$ respectively.

Table 3: Results for Equation (2).

\begin{tabular}{|c|c|c|}
\hline $\begin{array}{l}\text { Variable } \\
\text { Name }\end{array}$ & Definition & $\begin{array}{c}\text { Model } 2 \\
\text { OwnGDP } \\
\end{array}$ \\
\hline$\widehat{\operatorname{lnRec}} t_{t}$ & Estimated $\log$ of tourism receipts of country $i$ in period $t$ & $\begin{array}{c}0.0000000011 \\
(0.064)^{*}\end{array}$ \\
\hline$F D I_{t-1}$ & Foreign Direct Investment of country $i$ in period $t-1$ & $\begin{array}{c}1.9313 \\
(0.0000)^{* * *}\end{array}$ \\
\hline Pop $_{t}$ & Population of country $i$ in period $t$ & $\begin{array}{c}9620.769 \\
(0.0000)^{* * *}\end{array}$ \\
\hline Dcycl2 ${ }_{t}$ & Extreme weather events (cyclones) & $\begin{array}{c}-0.0000000269 \\
(0.5090)^{* *}\end{array}$ \\
\hline cons & Constant & $\begin{array}{c}-0.000000004 \\
(0.0030)^{* * *}\end{array}$ \\
\hline
\end{tabular}

$* * *, * *, *$ significant at $1 \%, 5 \%$ and $10 \%$ respectively.

\subsection{Analysis of results}

The results for equation 1 indicate that the impact of the inertial effect of travel in the previous year on tourism receipts in the current year is positive and significant. This inertial effect represented by the auto regressive lagged dependent variable captures return visits based on habit persistence and the 'word of mouth (WOM) effect' spread via 'blogs', both of which are based on prior positive travel experiences as they remove the uncertainty element for returning and new travellers to the region. This variable also captures return 
visits by former nationals residing abroad who travel to the region to visit family and friends [22]. The majority of tourist travel to the Melanesian FICs originates in Australia, whereas the majority of travel to the Polynesian FICs originates in New Zealand where former Samoan and Tongan citizens now reside.

Purchase decisions relating to travel are usually made in advance of the actual travel date [22]. The results of the lagged GDP representing past income indicate that an increase in Australian income decreases travel to these FICs, whereas for New Zealander and US citizens, an increase in income increases visits to these FICs. As mentioned before the impact of capital expenditure in the tourism sector on tourism receipts is not significant and is probably correct. These FICs do recognise that the sector lacks the infrastructure to support tourism in the areas of transportation and road networks especially in remote areas [5]. In addition the level of private investment, past and present, in the sector does not seem to generate a sufficient number of visitors per annum, especially in Samoa, Tonga and Vanuatu.

The results for equation 2 indicate that tourism has a positive and significant impact on GDP as do the level of FDI in the previous year. The impact of the control variable population as expected is also positive and significant on the GDP of these countries. Extreme weather, represented by years in which severe tropical cyclones occurred in this region, has the right sign, in that a cyclone is expected to affect GDP in equation 2 and tourism receipts in equation 1 negatively, but is not significant in model 2 as well. Thus no conclusion can be reached except that perhaps a better proxy is required to represent extreme weather or since severe cyclones occur generally between November and April in this region using monthly or quarterly data may produce a better result. Gathering consistent and appropriate data is a challenge with respect to these FICs and not always possible. It is also possible that the impact of return visits by former nationals especially in December to visit relatives is sufficient to mitigate the impact of reduced travel due to extreme weather.

\section{Climate change and extreme weather in FICs}

Although the impact of extreme weather is inconclusive in this study, both the impact of climate change and extreme weather are recognised by the FICs as factors of paramount importance to the strategic and sustainable development of the tourism sector. Tourism is both climate dependent and weather sensitive and these FICs have become increasingly dependent on the sector for their general economic well-being and in some cases survival. Climate characterises a location based on that location's meteorological long term average conditions. Given the climate at a particular point in time weather refers to the state of the atmosphere at that time [22].

Climate variability has been associated by many with the El Niño Southern Oscillation (ENSO). The ENSO and its connection to climate are used by many meteorological agencies to produce monthly weather forecasts. Swings in the Southern Oscillation Index (SOI) are associated with El Niño (sustained negative 
values of the SOI) and La Niña (sustained positive values of the SOI) events. Generally, tropical cyclones are more frequent during years when La Niña conditions prevail $[22,23]$. Based on the prevailing ENSO over the preceding July to September period, the Australian Bureau of Meteorology (BOM) is able to predict, with a fair degree of accuracy, the number of cyclones that are likely to occur in the western region of the South Pacific during the November to April period in the subsequent year. Predictions are less accurate for the eastern region. However in either case the BOM is unable to predict the exact strength and path including whether the cyclone will make landfall [23].

For the islands located in the Oceania region, the potentially serious climate change impact is the rise in sea levels and its possible impact on the coastal population and tourism resorts. Among the four FICs in this study, Fiji and Samoa have been identified as particularly vulnerable to a rise in sea levels $[8,24]$. Apart from sea level rise climate change could also destroy coral reefs, beaches and other inland tourism assets. The potentially serious extreme weather event is a severe tropical cyclone which could devastate the population and economy of all four FICs. Cyclones could prevent popular tourist activities such as swimming and snorkelling, cause damage to accommodation and infrastructure resulting in cancellations of travel bookings. Fiji has proven particularly vulnerable experiencing ten cyclones of category 3 or above during the period 1996 to 2011. In comparison Samoa experienced 1, Tonga 2 and Vanuatu 4 cyclones of similar strengths during this period. However, Samoa and Tonga also experienced devastation and flooding due to a Tsunami that occurred in 2009 [23].

\section{Strategies for the future and conclusions}

It is clear from the preceding discussion that the tourism sector is an important element in sustaining the economies of all four FICs though to varying degrees and for different reasons. Of the four economies Fiji is the most developed and also the largest tourist destination within the Melanesian and Polynesian regions of the South Pacific. In the other three FICs the level of development of the tourism sector is not only similar but concentrated on the main islands with less development in remote regions. All four FICs have progressed beyond the traditional destination management techniques of advertising campaigns and other promotions to well developed and tightly controlled websites with direct and indirect online means of communication and trading. However, the marketing of these destinations requires more than well maintained websites and the ease with which a tourist could purchase hotel accommodation within these FICs.

Currently, the majority of the visitors to these islands are from the Oceania region. Even the tourists on cruise ships that call on these islands are mostly Australian. If these islands are to sustain their tourism sector well into the future they need to look beyond Oceania and returning tourists to attracting new tourists and from other regions. Visitors to these FICs from beyond Oceania are 
mostly from the US. These FICs could benefit from destination managers who could expand their market capabilities. Further, current source markets may not be sufficient to sustain the sector in these FICs with growing competition for tourist dollars from other parts of the world. China could be an important source market given that Chinese outbound tourists are expected to outstrip the United States by 2023 [2].

The FICs do recognise their limitations with respect to long term sustainability of the sector. The linkages between tourism and transportation and tourism and agriculture specific to each FIC has been considered in terms of improving and extending road networks to facilitate tourism to remote areas and to link agricultural areas to markets. Strengthening the supply chain for tourism consumption products has also been explicitly recognised as an area for policy concern as the exposure of tourists to local produce would support and facilitate export market penetration $[3,20]$.

On a regional level, co-operation in the co-ordination of aviation expansion needs is seen as critical to tourism growth. The linkage between passenger aviation services and freight capacity for fresh export produce is recognised as crucial to improving the viability of increased airline services within the region. Another area recognised for a regional initiative is the potential for increasing the number of international cruise ship destinations and port calls within the South Pacific. Currently Vanuatu leads the way with 252 port calls in 2013. Fiji had 77 calls while Samoa and Tonga had less than 20 port calls [5, 20]. Destination managers could be employed to create awareness of the possibilities within the region among potential cruise passengers and cruise operators. In addition Government support is required in terms of the infrastructure requirements of such an initiative although these ships have little impact on life in these FICs as the port call is usually limited to a day.

The coastal nature of tourist attractions in these FICs underline the necessity for studying the impact of rising sea levels and extreme weather events on the tourism sector. In Samoa, relocating beach fales (a thatched hut) away from the beach is not an option and further they are not insurable [8]. In Fiji, the Mamanuca Islands (low lying atolls) are extremely vulnerable to cyclones and rising sea levels. Equally, the long term viability of the Fijian tourism industry itself which is predominantly linked to marine environments is at risk from these phenomena [24]. A similar scenario exists in Tonga and Vanuatu. Tackling the overall climate change impact has to be a regional initiative given the financial and non-financial resource requirements although applications would require initiatives that are island specific. The identification of indicators, monitoring and measurement requirements is best addressed at regional level. Specific scenario analysis would have to be island specific in order to assess future vulnerabilities and determine adaptation patterns if the sector is to be sustainable in the future. Developing and improving the early warning systems and the sharing of information on extreme weather events is a regional responsibility. Risk management strategies to cope with such events would be island specific.

Promoting sustainable tourism also requires recognising the negatives of tourism growth and its impact on the lives of the people and the economy. 
Tourism development must be accepted by the residents as it would undoubtedly change their way of life. Anecdotal evidence as well as literature suggests that many residents of these islands do not want a change in their traditional way of life $[25,14]$. Samoa's approach to tourism growth has always been cautious such that it respects the fa'aSamoa - the traditional way of life [14]. In Fiji, the life of the people is quite diverse depending on the village and the majority do not want drastic changes [25]. In Tonga, the King determines the way of life, for example, the change from whale hunting to whale watching based on a royal decree [17]. In Vanuatu, much of tourism is concentrated in Efate [20], whereas the rural population who are mostly unaffected outnumber the urban population 3:1 [Table 1]. However, the 2014 Lelepa Declaration [26] makes clear the value placed on the traditional economy and the rights of customary land owners. Unless these sentiments are respected in any planning for increased growth in the sector a long term strategy would be jeopardised.

Other negatives include the loss of cultural and natural assets and prime agricultural land due to infrastructure development to sustain tourism. Negative environmental impacts such as deforestation, crowding, potential pollution and problems with waste disposal and sanitation may also result from poor planning. Addressing these issues would require a long term commitment of financial resources as well as human resource development through training programmes targeting the labour force and educational programmes targeting schools. In addition forums to disseminate information on the impact on the traditional way of life and to assess the reaction of the residents of the affected area are required.

In conclusion, promoting sustainable tourism in FICs would require financial and non-financial resources which are scarce in these countries with competing development needs. As has been recognised by these FICs, regional co-operation and collaboration is vital. The framework already exists in the form of the FIC group which meet annually to address such issues and use their feedback mechanism to assess progress and target areas for additional support and resources. The group includes Australia and New Zealand who have long supported the budgetary and other requirements of their neighbouring island economies. The group also includes international organisations, which fund specific programmes, as observers. Such financial support is vital for strategic decision making to fund major initiatives especially in dealing with the challenge of climate change and exploring different adaptation options for the tourism industry. Funding is also vital for improving the current early warning system and assistance in the event of an extreme weather event. Ensuring the continuance of such support requires a commitment by these FICs of honest assessment and feedback. For the present, if policymakers can identify their core areas of competence and build on it, then they can build up their resilience against short term shocks with tactical decisions which do not require a long term commitment of resources. Strengthening their core areas of competence would also give them the flexibility to then focus more resources on long term sustainability. 


\section{References}

[1] Gössling, S., (ed). Tourism and Development in Tropical Islands: Political Ecology Perspectives, Edward Elgar Publishing, 2003.

[2] Travel \& Tourism: Economic Impact Oceania 2014; World Travel \& Tourism Council (WTTC), London, UK, www.wttc.org.

[3] Pacific Plan 2012 Annual Progress Report; Pacific Islands Forum Secretariat, Fiji, www.forumsec.org.

[4] Pacific Islands Forum Secretariat, Fiji, www.forumsec.org: Accessed $20^{\text {th }}$ February 2014.

[5] Tourism as a Pillar of Economic Growth; Pacific Islands Forum Secretariat, Fiji, www.forumsec.org.

[6] GDP ranking 2012. www.data.world.org/data-catalog/GDP-ranking-table: Accessed $20^{\text {th }}$ February 2014.

[7] Travel \& Tourism: Economic Impact Fiji 2013; World Travel \& Tourism Council (WTTC), London, UK, www.wttc.org.

[8] National Tourism Climate Change Adaptation Strategy for Samoa 2012-2017: Samoa Tourism Authority.

[9] Travel \& Tourism: Economic Impact Tonga 2013; World Travel \& Tourism Council (WTTC), London, UK, www.wttc.org.

[10] Travel \& Tourism: Economic Impact Vanuatu 2013; World Travel \& Tourism Council (WTTC), London, UK, www.wttc.org.

[11] Prasad, C. P. \& Narayan, P. K., Reviving growth in the Fiji islands: are we swimming or sinking? Pacific Economic Bulletin, 23(2): pp. 5-26, 2008.

[12] Narayan, P. K., Narayan, S. Prasad, A. \& Prasad, B. C., Tourism and economic growth: a panel data analysis for Pacific Island countries. Tourism Economics, 16(1): pp. 169-183, 2010.

[13] Fiji Bureau of Statistics, Fiji, www.statsfiji.gov.fj: Accessed $27^{\text {th }}$ February 2014.

[14] Pearce, D. G., Tourism planning in small tropical islands: methodological considerations and development issues in Samoa. Études caribéennes, 9-10 April-August 2008 http://etudecaribeennes.revues.org.

[15] Twining-Ward, L. \& Butler, R., Implementing STD on a small island: development and use of sustainable tourism development indicators in Samoa. Journal of Sustainable Tourism, 10(5): pp. 363-387, 2002.

[16] Samoa Bureau of Statistics. http://www.sbs.gov.ws. Accessed $27^{\text {th }}$ February 2014.

[17] Kessler, M. \& Harcourt, R. Aligning tourist, industry and government expectations: A case study from the swim with the whales industry in Tonga. Marine Policy, 34: pp. 1350-1356, 2010.

[18] Tonga Department of Statistics. http://www.spc.int/prism/tonga. Accessed $27^{\text {th }}$ February 2014.

[19] Kumar, R. R., Naidu, V. \& Kumar, R., Exploring the nexus between trade, visitor arrivals, remittances and income in the Pacific; a study of Vanuatu. OECONOMICA, 7(4): 2011. 
[20] Cassidy, F. \& Brown, L., Determinants of small Pacific island tourism: a Vanuatu study. Asia Pacific Journal of Tourism Research, 15(2): pp. 143-153, 2010.

[21] Vanuatu National Statistics Office. http://www.vnso.gov.vu. Accessed $27^{\text {th }}$ February 2014.

[22] Saverimuttu, V. \& Varua, M. E., Climate variability in the origin countries as a "push" factor on tourist arrivals in the Philippines. Asia Pacific Journal of Tourism Research, 2013. http://dx.doi.org/10.1080/10941665.2013.806940.

[23] Bureau of Meteorology, Australia. http://www.bom.gov.au.

[24] Moreno, A. \& Becken, S., A climate change vulnerability assessment methodology for coastal tourism. Journal of Sustainable Tourism, 17(4): pp. 473-488, 2009.

[25] Kerstetter, D. \& Bricker, K., Exploring Fijian's sense of place after exposure to tourism development. Journal of Sustainable Tourism, 17(6): pp. 691-708, 2009.

[26] The Lelepa Declaration 2014, Pacific Islands Report Pacific; Pacific Islands Development Program, East-West Center, March 2014. http://pidp.eastwestcenter.org/pireport/2014/March/03-27-st.htm. 